\title{
REDISCOVERY OF CAMPANULA MACROSTACHYA WALDST. \& KIT. EX WILLD. IN THE BÜKK FOOTHILLS
}

\author{
András Schmotzer ${ }^{1 *}$ \& Jana Táborská ${ }^{2}$ \\ ${ }_{1}^{1}$ Bükk National Park Directorate, Sánc u. 6, H-3304 Eger, Hungary; \\ 2 Department of Botany and Plant Physiology, Eszterházy Károly University, \\ Leányka u. 6, H-3300 Eger, Hungary; *E-mail: schmotzera@bnpi.hu
}

\begin{abstract}
The single recent stand of the strictly protected Campanula macrostachya Waldst. \& Kit. ex Willd. from the Bükk Mts. is presented in this paper. This PonticPannonian-Balkanic element is rather scattered in the western and northern parts of its range and has been regarded in past decades as an "extinct" or "nonconfirmed" species in the Bükk Mountains. The occurrence of this species in this region was first documented as far back as 1910 by Gyula Prodán. The second and last occurrence was documented with a herbarium specimen by Rezső Soó in 1938. No proved occurrence had been known in the last seven decades from the region, until when in 2015 a new locality was found among orchards in a secondary steppe grassland in the Bükk foothills, close to the village of Szomolya. This contribution also includes a description of the habitat based on three phytosociological relevés, a photocopy of the voucher specimen and a line drawing of the species.
\end{abstract}

Keywords: Campanulaceae, distribution, rediscovery, Bükk Mts., habitat preference

\section{INTRODUCTION}

Campanula macrostachya Waldst. \& Kit. ex Willd. (syn.: C. macrostachya Willd.; C. multiflora Walds. \& Kit.; C. cervicaria subsp. macrostachya (Waldst. \& Kit. ex Willd.) Tacik) is a lowland-colline, Pontic-Pannonian-Balkanic flora element (Fedorov 1957, Soó 1968, Fedorov and Kovanda 1976). According to current knowledge, it is distributed from the Ukrainian steppe zone through Anatolia and the Balkan Penninsula to the Carpathian Basin (Meusel and Jäger 1992). The occurrence of the species in the Balkans is restricted to the eastern and central parts, including Serbia, Montenegro, Macedonia, Bulgaria, Greece (Thrace) and the European part of Turkey (Obradović 1974, Damboldt 1978, Kovačić 2004, Teofilovski 2011, Kožuharov and Anchev 2012). It was recently clarified that the 
species was erroneously reported from Albania (Barina et al. 2016). A taxon described as C. macedonica by Boissier (1875) is treated now as the synonym of $C$. macrostachya (EURO+MED 2006). The species is also present in Eastern Europe, with sporadic data known from the eastern parts of Romania and Moldavia (Oprea 2005, Ciocârlan 2009, Shabanova et al. 2014). As many other steppe and forest-steppe plants, this species also reaches its western and northern distribution limit in the Carpathian Basin (Sag and Gotthard 1985, Holub 1999, Fekete et al. 2011). In the Carpathian Basin, it occurs in Romania (Transylvania), southern Slovakia and northern Hungary (Oprea 2005, Marhold and Hindák 1998, Goliašová et al. 2008, Király 2009). The Slovak and Hungarian populations are partly distributed in the same phytographical region ("Matricum"). Its native range is rather disjunct, showing regression especially at the western and northern borders of its range.

Campanula macrostachya is also a rare, scattered plant in Hungary. It occurs on warm, southern-faced slopes in hilly areas from the Balaton Uplands to the Bükk Mountains and on one volcanic hill on the Bereg Plain (Király 2009). In most of the regions $C$. mactostachya has only been reported from few (usually less than 3) locations (e.g. Börzsöny Mts. /Nagy 2007/, Cserhát /Malatinszky et al. 2014/, Bereg Plain / Fintha 1994/). The occurrence of the species in the Gerecse Mountains has recently proved unconfirmed and the data in question are now considered to be an error (Barina 2006). The most viable populations of the species occur around Budapest (esp. Visegrád Mts and Pilis; Bőhm 2001, Barina 2004) and in the Mátra Mts (Soó 1937, Sramkó et al. 2008). Further localities of the species were mapped during the last decade in the Mátra Mts. (Magos G. pers. comm.). The species' recent distribution is indicated from 13 grid quadrates in the flora atlas of Hungary (Bartha et al. 2015).

Campanula macrostachya is a strictly protected plant species in Hungary and in Slovakia. Due to its rarity and phytogeographic importance, the species is also included in national and regional red lists. According to the Hungarian and the Slovakian red lists the species is evaluated as "endangered" (EN) (Király 2007, Eliáš et al. 2015). The species was also included in regional red lists, especially in a Carpathian regional context. In the Carpathians, it was categorised as "vulnerable" (VU) (Witkowski et al. 2003) or recently as "near threatened" (NT) (Turis et al. 2014a). The species was also 
evaluated as "endangered" in the Carpathian part of Slovakia (Turis et al. 2014b).

The objectives of this study are (i) to present the current occurrence of the species in the Bükk Mts. and (ii) to characterise its newly discovered locality and remark on its future prospects.

\section{MATERIALS AND METHODS}

\section{The study species}

As many other Pannonian plant species, C. macrostachya was discovered by Jacob Winterl, who named it Campanula petraea (Winterl 1788). His descriptions and nomenclatures were not valid, so the valid description was published, inter alia, by Willdenow (1809), based on the collection of Waldstein and Kitaibel (Kováts 1992, Barina 2014). They described and presented the species as Campanula multiflora in the third volume of their master work, "Descriptiones et Icones Plantarum Rariorum Hungariae" (Waldstein and Kitaibel 1811).

Campanula macrostachya belongs to the Involucratae (Fomin) Charadze subsection of the Campanulaceae family. This subsection is characterized by sessile flowers that are crowded in heads, whorls or clusters and flowers are enveloped by large bracts, which facilitate secondary diaspore presentation (Fedorov 1957). Species of this subsection are usually more or less densely pubescent. The closest relatives of this species in the Pannonian flora district are Campanula glomerata $\mathrm{L}$. and C. cervicaria $\mathrm{L}$. It is a typical short lived perennial herbaceous species, which means that the plant grows longer than one year vegetatively before completing its life cycle after the first and only generative reproduction. Despite that, some authors treat $C$. macrostachya as a biennial plant (e.g. Damboldt 1978, Ciocârlan 2009).

The plants are up to $70 \mathrm{~cm}$ tall, the stem is erect, simple, striate and leafy. The basal leaves are crenate or entire, withered at anthesis; cauline lanceolate, sessile, the uppermost ovate-lanceolate, cordate. Flowers are in clusters of 3-5. The inflorescences are branched, interrupted-spicate. The calyx-teeth are lanceolate, $1 / 3$ as long as the corolla. The corolla is narrowly infundibular, $10-15(-20)$ $\mathrm{mm}$ long, usually pale-violet blue. The capsule is obconical, constricted at apex, 4-5 × 2-3 mm and opening by 3 small capsules (Fedorov \& Kovanda 1976, Király 2009; Figure 1). Actual 
karyological data on tetraploid populations occurring in Hungary $(2 \mathrm{n}=32$; locality: Visegrád Mts.) were reported by Michalková (2007).

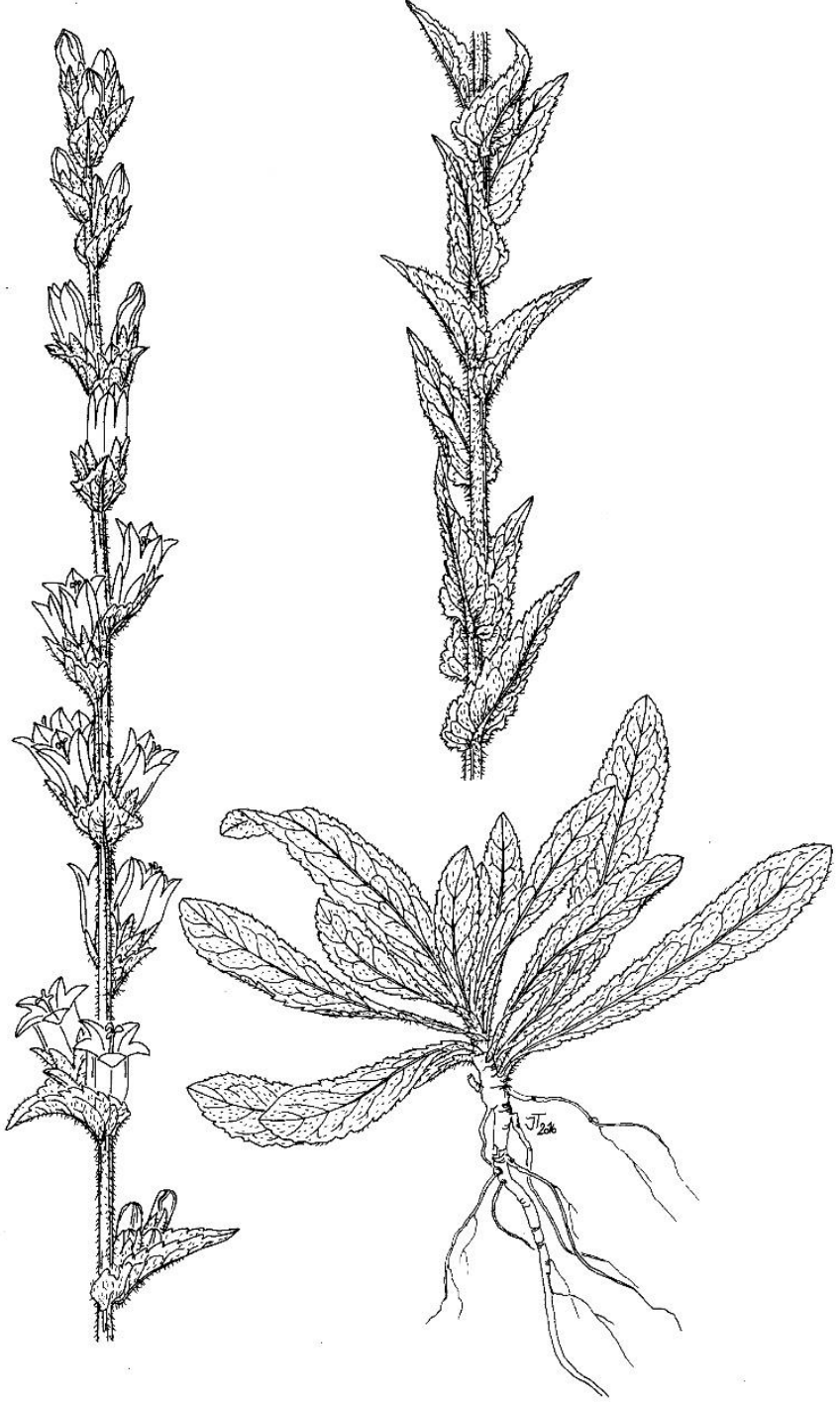

Figure 1. Campanula macrostachya Waldst. \& Kit. ex Willd. (drawn by J. Táborská). 


\section{The study area}

The Bükk Mountains belong to the inner range of the Carpathians (as part of the Western Carpathians, see Kondracki 1978) and are different from the neighbouring mountains both in origin and structure. The area is very diverse petrographically, includes a massive part of cavernous limestone on the Bükk Plateau (Sütő et al. 2015), complemented by other non-karstic rocks (such as porphyry, slate shale and basalt). The Bükk foothills ("Bükkalja") as a separate landscape are petrographically varied, the young surface was formed by volcanites (ignimbrite, rhyolite, rhyolite tuff), covered with Pliocene and Pleistocene deposits (e.g. sand, marl and loess; Balogh 1964, Pelikán 2005). The whole area of the Bükk Mts belongs to the Borsodense flora-district of the Matricum flora-region of the Pannonian flora province. It is the largest area with the most varied flora and vegetation not only of the Hungarian Northern Mountain Range but of the whole of Hungary. Floristically it is even more interesting that dealpine-glacial and sub-Mediterranean-interglacial and, moreover, cold-continental species can be found here, and endemic and sub-endemic plants are also notable (Vojtkó 2001). The presence of steppe and forest steppe species are also remarkable, especially on the Bükk foothills and in the southern Bükk Mts (Schmotzer 2015).

\section{Data acquisition and processing}

The field work was carried out during the years 2015 and 2016. Concentrating on the occurrences of C. macrostachya in the Bükk Mts. and its surroundings, the relevant herbarium collections were studied. The primary data were obtained from specimens in herbarium collections, but only one specimen of the species was found from the Bükk Mts. in the collection of the Herbarium CarpatoPannonicum Budapest (BP). The vascular collection of Eszterházy Károly University (EGR) was also checked. The online herbarium database of Debrecen University collections (DE) (Takács et al. $2015 \mathrm{a}, \mathrm{b}$ ) was also investigated. All literature data were evaluated in this study, including non-reliable secondary data, published in regional and national publications. As for related papers, we tried to detect the original data sources. Data without precise coordinates were indicated (e.g. old records without any lower toponyms). In such a case the more suitable location for the species was chosen in the process of the GIS interpretation. The CEU grid numbers added 
follow the codes of the Central European Flora-mapping project (Niklfeld 1971, Király 2003). The distribution map was produced using ArcGIS 10.3 software. Geo-coordinates of the localities were determined using a Trimble Juno 3B GPS device in Hungarian EOV DATUM projection. The coordinates were converted to the WGS-84 system by the online application of Psoft Informatikai Ltd. (www.psoft.hu). Online historical maps of the Habsburg Empire and cadastral maps were used to study former land-use of the study area (http://mapire.eu/en/).

For describing the habitat conditions of the discovered new locality, we carried out three phytosociological relevés, according to the Central-European Phytosociological School method (BraunBlanquet 1932). We sampled vegetation patches where Campanula macrostachya covers at least $0.5 \%$ of the relevé size. We presented percentage cover data for the vascular plant species. Coverage below $0.5 \%$ is indicated as "+" and the mark "a" is used to refer for accidental elements. Nomenclature of flowering plants is according to Király (2009). Nomenclature of plant syntaxa follows Borhidi et al. (2012).

The voucher specimen was deposited in the Herbarium CarpatoPannonicum collection of the Hungarian Natural History Museum, Budapest (ID number: BP7510721; Figure 2).

\section{RESULTS AND DISCUSSION}

\section{Discovery of the new locality of Campanula macrostachya in the Bükk foothills}

On 21 April 2015, the first author carried out spring-time floristic mapping in the Bükk foothills to gather additional protected or vulnerable plant species within the framework of an intensive floramapping of the region (see Schmotzer 2015). While collecting GPS data of e.g. Orchis morio, Thlaspi jankae, Prunus tenella, Vinca herbacea, he found some basal leaves which resembled Campanula macrostachya. The verification of this identification was made on 7 July 2015 , when the plants were in late flowering state. We revisited the site on 16 June 2016, estimated the population size, expanded the flora-list of the locality and carried out the phytosociological relevés. 


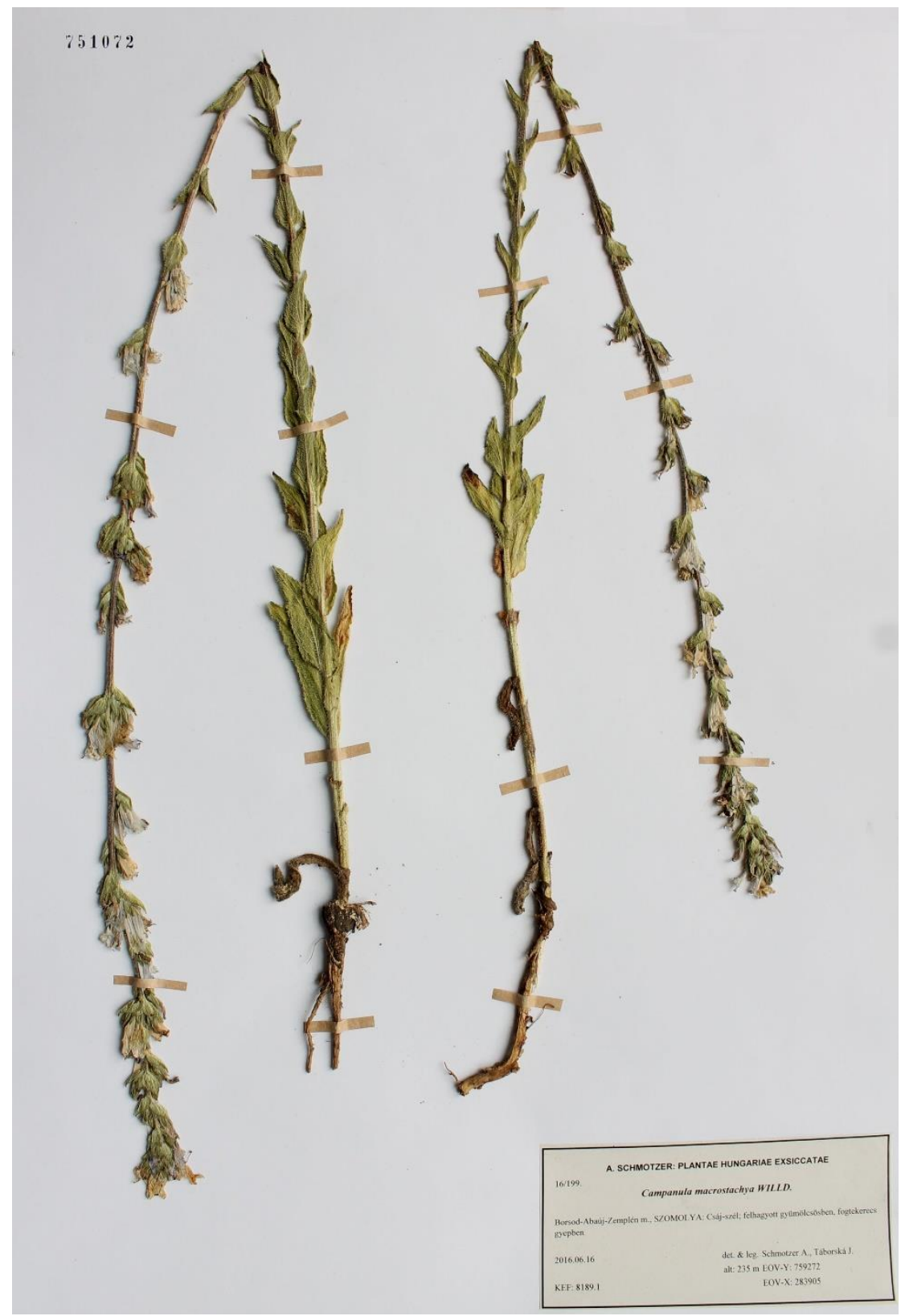

Figure 2. Voucher specimen of Campanula macrostachya (ID number: BP7510721) (photo by Cs. Németh). 
The locality is situated on Gyür Hill (in Hungarian: "Gyür-tető"; part "Csáj-szél"), approx. 300 metres east of Szomolya village (BorsodAbaúj-Zemplén county, North-Hungary; CEU mapping unit: 8189/1). The average height of the locality is $230-235$ metres a.s.l. Centroid coordinates of the locality are $47.8896^{\circ} \mathrm{N}$ and $20.5086^{\circ} \mathrm{E}$.

We found an estimated 450 individuals on the site, counting only the flowering individuals. The exact number of individuals is supposed to be at least two times higher, due to the species life-form trait.

\section{Habitat characterisation of the locality}

Gyür Hill is a typical example of former land use in the Bükk foothills. Small patches of cultivated land (especially orchards with the wellknown black fruited cultivar of "Szomolya cherry") and abandoned parcels coexist with noteworthy remnants of natural vegetation patches (semidry grasslands and thickets). The habitat of Campanula macrostachya is situated next to a cherry tree orchard on a dry grassland sparsely covered by thermophile shrubs (Figure 3).

The extent of the locality where the Campanula macrostachya individuals grow is approximately 0.2 hectares. The size of the grassland - thicket patches among the cultivated pieces of land - is rather small, altogether less than 2 hectares. According to historical maps, formerly the site was probably also an orchard and/or vineyard. The grassland is not uniform in terms of dominant grasses and herbs; the patchy structure of areas dominated by different herb and forb species is remarkable. The bedrock is a volcanic tuff (belonging to Harsány Rhyolite Tuff Formation, Pelikán 2005), the topsoil layer is rather shallow.

The species composition of the locality belongs to the Cirsio pannonicae-Brachypodion Hadač et Klika alliance, but closer vegetation syntaxon is not possible to determine. Altogether 41 species occur in the three relevés (Table 1). The shrubby patches are mostly formed by Prunus spinosa, Rosa canina s.l.. and Crataegus monogyna, but along verges, notable stands of Amygdalus nana, Rosa gallica, Acer tataricum and Cydonia oblonga as a remnant of cultivation exist. The presence and expansion of the invasive Robinia pseudo-acacia is the most significant threatening factor on the site. The cover of grasses is rather variable, Danthonia alpina, Bothriochloa ischaemum and Calamagrostis epigeios being the most abundant species. The latter two grasses indicate degradation on the 
locality, but also take part in the natural regeneration phase in secondary succession (Baráth 1963).

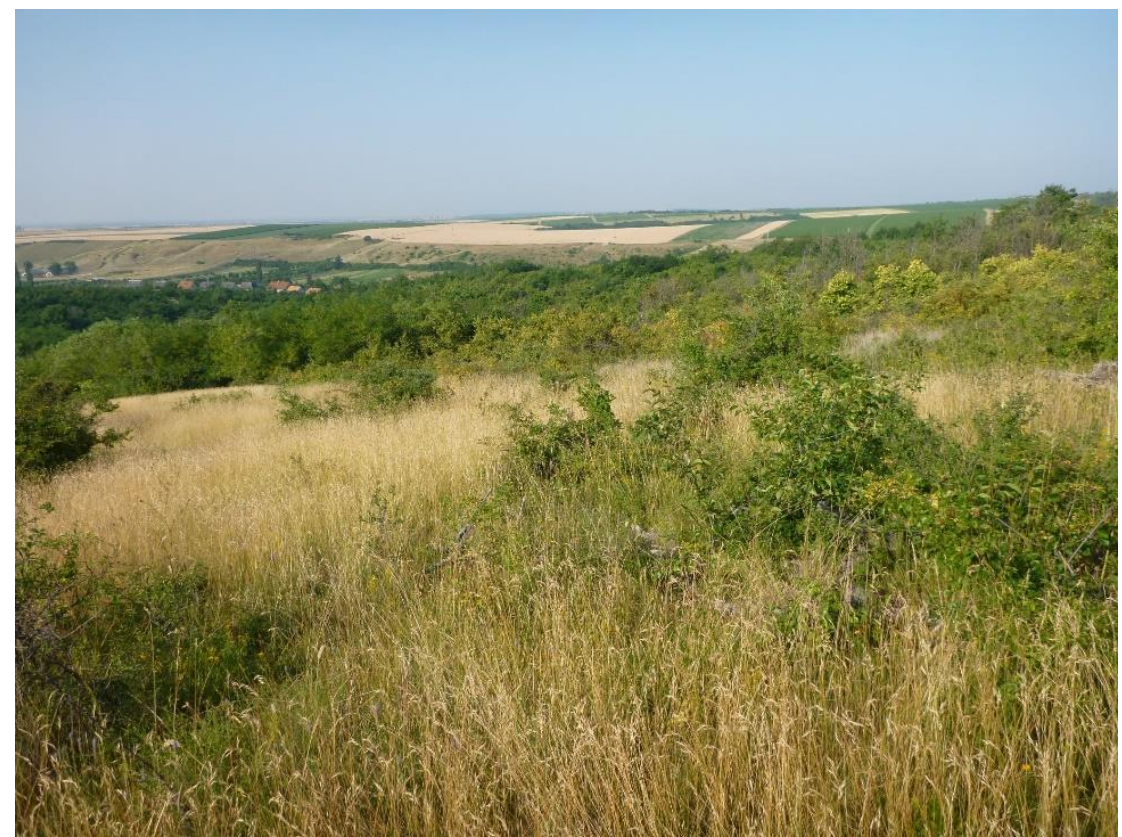

Figure 3. Habitat of Campanula macrostachya at village of Szomolya village (7 July 2015) (photo of A. Schmotzer).

Grasses with lower abundance and cover are also observed (an asterisk (*) indicates species which occur outside of the relevés), such as Koeleria cristata, Festuca valesiaca*, Poa angustifolia, Helictotrichon compressum*, Bromus japonicus, B. hordeaceus*, Alopecurus pratensis, Elymus repens and Ventenata dubia. The core of the grassland is formed by generalist Festuco-Brometea and Festucetalia species, e.g. Fragaria viridis, Galium verum, Potentilla recta, Pseudolysimachion orchideum, Trifolium montanum, T. alpestre, Dorycnium herbaceum, Verbascum phoeniceum*, Orchis morio*, Vinca herbacea*. Tall-herb forbs and forest fringe dicots have a significant role in natural secondary succession, and are represented in the locality mostly by Asteraceae and Apiaceae species, such as Aster linosyris, Inula ensifolia, I. salicina, I. hirta*, I. germanica*, I. oculus-christi*, Centaurea scabiosa*, Peucedanum alsaticum, P. cervaria * and Seseli osseum. The presence of typical, 
regionally broadly distributed perennials (e.g. Artemisia pontica*, Thlaspi jankae*, Lychnis coronaria*, Ornithogalum brevistylum, Ranunculus pedatus*) and annual steppe species (e.g. Androsace elongata*, Xeranthemum cylindrceum, Tordylium maximum, Crepis pulchra*, Valerianella dentata) is also characteristic. The successional trend probably leads to the regeneration of the seminatural Danthonia alpina or Stipa spp. dominated grasslands, or the shrubby phase of the vegetation may be strengthened and a secondary, partly closed forest may develop.

Table 1. Floristic composition of the patch with Campanula macrostachya.

\begin{tabular}{|c|c|c|c|c|}
\hline Nr. of relevé & 1 & 2 & 3 & Freq. \\
\hline Cover of shrub layer in \% & - & 20 & - & \\
\hline Cover of herb layer in $\%$ & 76 & 93 & 85 & \\
\hline Height of shrubs in $\mathrm{cm}$ & - & 80-120 & - & \\
\hline Height of herbs in $\mathrm{cm}$ & $20-45$ & $30-60$ & $30-120$ & \\
\hline Species number & 26 & 26 & 18 & \\
\hline \multicolumn{5}{|l|}{ - Shrub layer - } \\
\hline Prunus spinosa & & 16 & & 1 \\
\hline Rosa canina s.l. & & 4 & & 1 \\
\hline \multicolumn{5}{|l|}{ - Herb layer - } \\
\hline Arenaria serpyllifolia & $\mathrm{a}$ & $\mathrm{a}$ & 0.5 & 3 \\
\hline Bromus japonicus & + & 1 & 1 & 3 \\
\hline Campanula macrostachya & 0.5 & 3 & 0.5 & 3 \\
\hline Danthonia alpina & 1 & 2 & 60 & 3 \\
\hline Fragaria viridis & 15 & 15 & 8 & 3 \\
\hline Galium verum & 5 & 5 & 5 & 3 \\
\hline Peucedanum alsaticum & 25 & 3 & 3 & 3 \\
\hline Potentilla recta & 5 & 6 & 1 & 3 \\
\hline Prunus spinosa & 6 & 15 & + & 3 \\
\hline Pseudolysimachion orchideum & 0.5 & 2 & + & 3 \\
\hline Xeranthemum cylindraceum & 5 & 30 & 0.5 & 3 \\
\hline Aster linosyris & 6 & 6 & & 2 \\
\hline Cerastium brachypetalum & + & + & & 2 \\
\hline Dorycnium herbaceum & + & 2 & & 2 \\
\hline Koeleria cristata & 1 & & 0.5 & 2 \\
\hline Lathyrus nissolia & $\mathrm{a}$ & $\mathrm{a}$ & & 2 \\
\hline Lepidium campestre & & + & + & 2 \\
\hline Poa angustifolia & + & 2 & & 2 \\
\hline Valerianella dentata & + & & + & 2 \\
\hline
\end{tabular}

Accompanying, accidental species (with the relevé number in brackets): Alopecurus pratensis 1 (2), Arabis glabra a (1), Bothriochloa ischaemum 1 (3), Crataegus monogyna 3 (1), Elymus repens + (3), Falcaria vulgaris a (2), Hypericum perforatum $+(2)$, Inula ensifolia 0,5 (3), I. salicina + (1), Lathyrus tuberosus $+(1)$, Ornithogalum brevistylum + (1), Odontites lutea 3 (3), Rosa canina s.l. a (2), Seseli osseum 1 (1), 
Tordylium maximum a (2), Torilis arvensis a (2), Trifolium montanum 1 (1), Ventenata dubia a (1), Veronica arvensis + (2), Vicia angustifolia a (2).

Relevés made by: András Schmotzer and Jana Táborská, Date: 07.07.2016., Location: Hungary, Borsod-Abaúj-Zemplén county, Szomolya village. Position (centroid): $47.8896^{\circ} \mathrm{N}$ and $20.5086^{\circ}$ E. Altitude: $230-235 \mathrm{~m}$. Exposition: south. Declination: $2-5^{\circ}$. Plot size: $4 \mathrm{~m}^{2}$.

\section{Critical evaluation of the distribution of Campanula macrostachya in the Bükk Mts}

As our investigation of herbarium specimens and literature data showed, Campanula macrostachya was reliably recorded before this present rediscovery in two localities in the Bükk Mts. Both localities are situated in the Bükk foothills. Some additional occurrence data were also included in this survey, but both are regarded erroneous, and neither herbarium specimens, nor precise literature data provision were added. The distribution map indicates the localities used in this chapter (Figure 4).

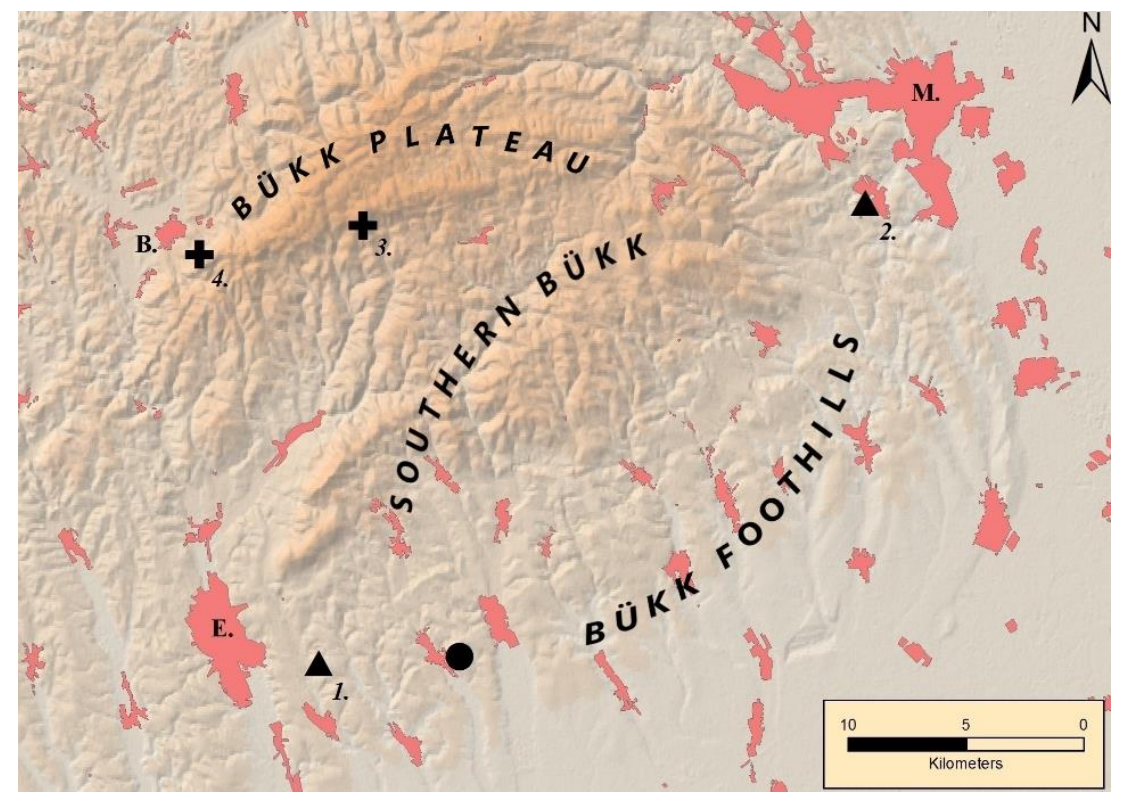

Figure 4. Distribution of Campanula macrostachya in the Bükk Mts. (Hungary): $\mathbf{\Delta}$ confirmed historical locations; $\bullet$ - recent location; + - erroneous locations; $\mathrm{E}=$ Eger; M. = Miskolc; B. = Bélapátfalva; numbers are referring to the locations (see text) (compiled by A. Schmotzer). 


\section{Confirmed historical data}

1. "Ostoros" (Heves County) - probable CEU grid: 8188/2.

The species was first reported from the Bükk by Gyula Prodán (1909). Unfortunately, he neglected to add detailed toponyms for his finding, only presented as " $C$. macrostachya $W x K$., on pastures in the vicinity of Ostoros". Nowadays no voucher specimen of this finding is known, but according to Samu Kupcsok, it was still available in 1912. He could have identified his Campanula sp. specimen collected at Bát village (Bátovce, Slovakia) as C. macrostachya based on a specimen that originated from Prodán's collection (Kupcsok 1912). Prodán's record was also quoted by Soó (1937) and Vojtkó (2001). Jávorka's note in his masterpiece Flora Hungarica could also refer to this data source, but he added the location as "at Eger town" (Jávorka 1925). The plant has not been found near Ostoros in the past decades, despite of intensive flora surveys that have taken place there (Pifkó and Barina 2004, Schmotzer 2015).

2. "Miskolctapolca" (Borsod-Abaúj-Zemplén County; also indicated as Görömbölytapolca, now belonging to the city of Miskolc) probable CEU grids: $7990 / 2$ or $7990 / 4$.

Rezső Soó found the species in Miskolctapolca in 1938. The voucher specimen is deposited in the Herbarium Carpato-Pannonicum Budapest (BP; ID number. 394203). The authentic label text is "Locus natalis cott. Borsod. mt. Bükk. in pratis siccis collinis pr. balneas G.Tapolca. 17.06.1938". Later he also added this finding to the preliminary flora evaluation of the Bükk Mts (Soó 1943). He also indicated in this work that Campanula macrostachya occurred there in vast individual numbers ("C. macrostachya Kit. Tapolca! dry grassland on a slope of a hill; plenty"). Vojtkó (2001) also added this record to his work as a piece of literature data.

The exact locality is not known precisely, but the surroundings of the 'Miskolctapolca Thermal Spa' have changed a lot in the last seven decades. Continuous urbanisation has destroyed several natural grasslands there. We have carried out a sporadic floristic investigation in the surrounding areas, but no locality of Campanula macrostachya has been found. Several small patches of semi-natural vegetation still occur at Miskolctapolca among orchards and gardens (Sonkoly 2014, Schmotzer 2015), so existing populations might be lying hidden. 


\section{Erroneous data}

3. "Tarkő" (Heves and Borsod-Abaúj-Zemplén County; belonging to Felsőtárkány or Szilvásvárad)

Only one piece of data was published from this location as "at Eger town and on Tarkô"' in Flora Hungarica (Jávorka 1925, Vojtkó 2001). No voucher specimen or closer data source is known.

The location is regarded as unsuitable for this species. Tarkő Rock (945 m a.s.l.) - as a member of the characteristic rocky cliffs bordering the Bükk Plateau - is formed by cavernous Triassic limestone. Campanula macrostachya prefers lower altitudes and warmer conditions and its distribution is usually limited to volcanic or sediment bedrocks. The locality has been studied continuously by florists and there is no source proving the occurrence of the species there (Vojtkó 2001).

\section{4. "Bélkő" (Heves County, belonging to Bélapátfalva)}

This locality was presented only in a monograph on protected plant species occurring in Hungary (Farkas 1999). The primary data source was also not evident and was not included in the flora monograph of the Bükk Mts. (Vojtkó 2001).

The location has similar natural conditions to those of Tarkő Rock (limestone as bedrock and higher altitude), so we assume that this is also an erroneous report of the species.

\section{CONCLUSIONS}

The data presented indicate that the strictly protected Campanula macrostachya has only one recent location in the Bükk Mts. It has been found nearly 80 years after the last confirmed report. Two former pieces of historical occurrence data have been confirmed (Ostoros, Miskolctapolca). On the other hand we have found two locations which should be erroneous and possibly deleted from the enumeration of the species in the Bükk Mts. The closest site of Campanula macrostachya occurs westwards in the Mátra foothills at a distance of about 38 kilometres from the Szomolya locality. This population at Feldebrő village was found by Csaba Molnár in 2004 (the voucher specimen is in the Herbarium Carpato-Pannonicum Budapest (BP; ID number 669318; see also Sramkó et al 2008). The documented locality in Bükk foothills is found outside of protected area, so its conservation deserves special attention in the future. The 
population is rather strong (assumed to be more than 500 individuals), but it is threatened by possible land use conversions (such as the creation of orchards and vineyards) and natural successional processes, especially black locust invasion.

Acknowledgements - The authors would like to thank our reviewers, Zoltán Barina and András Vojtkó (Eger) for their improvements to the manuscript. We are indebted to Zoltán Barina and Dániel Pifkó (Budapest; BP) for the herbarium assistance and to Verica Stojanović (Belgrade) for providing the Serbian literature concerning this species. The authors are grateful to Csaba Németh (Budapest) for photographing the voucher specimen. Thanks to Albert Vermes (Eger) who kindly improved the English of the revised version.

\section{REFERENCES}

BALOGH, K. (1964). A Bükk hegység földtani képződményei. A Magyar Állami Földtani Intézet Évkönyve 48(2): 245-719.

BARÁTH, Z. (1963). Növénytakaró vizsgálatok felhagyott szőlőkben. (Analyses of vegetation cover in abandonned vineyards). Földrajzi Értesítő 2(3): 341-356.

BARINA, Z. (2004). A Dunántúli-középhegység növényföldrajzának főbb jellemzői. (Characteristics of the phytography of Transdanubian Mountains in Hungary.) Flora Pannonica 2(2): 37-55.

Barina, Z. (2006). A Gerecse hegység flórájának katalógusa. (Flora of the Gerecse Mountains.). Magyar Természettudományi Múzeum - Duna-Ipoly nemzeti Park Igazgatóság, Budapest, 612 pp.

BARINA,Z. (2014). Kitaibel Pál (1757-1817) és a 21. század - mitől lesz „élő” egy 200 éves herbárium? (A 200-year-old "living herbarium" - bringing botanist Pál Kitaibel (1757-1817) into the 21st century). Annales historico-naturales Musei nationalis hungarici 106: 141-156.

Barina, Z., PifKó, D. \& Somogyi, G. (2016). The influence of Bruno Schütt (1876-1956) on Albanian floristic research. Phytotaxa 273(1): 1-22.

Bartha, D., KirÁly, G., Schmidt, D., Tiborcz, V., Barina, Z., Csiky, J., JAKAB, G., LeSkU, B., Schmotzer, A., Vidéкi, R., Vojtкó, A. \& ZólYomi, Sz. (2015). Magyarország edényes növényfajainak elterjedési atlasza. (Distribution atlas of vascular plants of Hungary.) Nyugat-magyarországi Egyetem Kiadó / University of West Hungary Press, Sopron, 329 pp.

BőHM, É. (2001). Florisztikai vizsgálatok a Duna-Ipoly Nemzeti Park dél-délkeleti peremén. (Floristical studies on the south-east edge of the Danube-Ipoly National Park (DINP), Hungary.) Kitaibelia 6(1): 51-71.

BoISSIER, E. (1875). Flora orientalis sive Enumeratio plantarum in Oriente, a Graeca et Aegypto ad Indiae fines hucusque observatarum. Vol. III. H. Georg, Geneva \& Basilea (Basel), $1033 \mathrm{pp}$.

Borhidi, A., KeveY, B. \& LendVAI, G. (2012). Plant communities of Hungary. Akadémiai Kiadó, Budapest, 544 pp.

Braun-Blanquet, J. (1932). Plant sociology (Transl. Fuller, G.D \& Conrad, H.S.). McGraw-Hill, New York, 539 pp. 
Ciocârlan, V. (2009). Flora ilustrată a României. Pteridophyta et Spermatophyta. Edit. Ceres, Bucureşti, $1141 \mathrm{pp}$.

DAmboldT, J. (1978). Campanula. In: Davis, P.H. (ed.): Flora of Turkey and the East Aegean Islands, vol. 6: 2-64. Edinburgh Univ. Press, Edinburgh.

Eliáš jun., P., DítĚ, D., KLIMENT, J., HRivnÁK, R. \& FeráKovÁ, V. (2015). Red list of ferns and flowering plants of Slovakia, 5th edition (October 2014). Biologia (Bratislava) 70(2): 218-228.

EuRo+Med (2006). Euro+Med PlantBase, the information resource for EuroMediterranean plant diversity. Published on the Internet http://ww2.bgbm.org/EuroPlusMed/ [accessed 12.11.2016].

FARKAS, S. (1999). Magyarország védett növényei. (Protected plants of Hungary). Mezőgazda Kiadó, 416 pp.

Fedorov, A.A. (1957). Campanulaceae. In: SHIShrin B.K. (ed.): Flora of the SSSR. Moskow. Akademii Nauk SSSR, pp. 92-321.

Fedorov, A.A. \& Kovanda, M. (1976). Campanula. In: Tutin, T.G., Heywood, V.H., Burges, A., Moore, D.M. \& Valentine, D.H. \& al. (eds.): Flora Europaea. Cambridge: Cambridge University Press, pp. 74-93.

Fekete, G., Molnár, Zs, Magyari, E., Somodi, I., Varga, Z. (2011). Egyediség, szabályszerűség és deviáció a Pannon Régió vegetációjának példáján. (Individualities, regularities and deviations: example of the vegetation in the Pannonian Region.). Botanikai közlemények 98(1-2): 29-59.

FinTHA, I. (1994). Az Észak-Alföld edényes flórája. TermészetBúvár Alapítvány Kiadó, Budapest, $130 \mathrm{pp}$.

GoliašovÁ, K., Michalková, E. \& Mráz, P. (2008). Campanula L. In: Goliašová, K. \& Šípošová, H. (eds.). Flóra Slovenska VI/1. Veda, Vydavatel'stvo SAV, Bratislava, pp. 276-279.

Holub, J. (1999). Campanula macrostachya. In: ČeŘovsKÝ, J., FeráKovÁ, V., Holub, J., MAGLOCKÝ, Š. \& PROCHÁZKA, F. (eds.): Červená kniha ohrožených a vzácných druhů rostlin a živočichů $\breve{C} R$ a SR. Vol. 5. Vyšší rostliny [Red Data Book of threatened plants and animals of the Czech Republic and Slovak Republic. Vol. 5. Higher plants]. Príroda, Bratislava. p. 70.

JávoRKA, S. (1925). Magyar Flóra (Flora Hungarica). Studium Kiadása, Budapest, $1307 \mathrm{pp}$.

KIRÁLY, G. (2003). A magyarországi flóratérképezés módszertani alapjai. Útmutató és magyarázat a hálótérképezési adatlapok használatához. (Methodik und Ziele der Florenkartierung in Ungarn). Flora Pannonica 1(1): 3-20.

KIRÁLY, G. (ed., 2007). Vörös Lista. A magyarországi edényes flóra veszélyeztetett fajai. (Red list of the vascular flora of Hungary). Saját kiadás, Sopron, $73 \mathrm{pp}$.

KIRÁLY, G. (ed., 2009). Új magyar füvészkönyv. Magyarország hajtásos növényei. Határozókulcsok. (New Hungarian Herbal. The vascular plants of Hungary). Aggteleki Nemzeti Park Igazgatóság, Jósvafő, 616 pp.

Kondracki, J. (1978). Karpaty, Wydawnictwo Szkolne i Pedagogiczne. Warsaw.

Kovačıć, S. (2004). The genus Campanula L. (Campanulaceae) in Croatia, circumAdriatic and west Balkan region. Acta Bot. Croat. 63(2): 171-202.

KovÁTs, D. (1992). Waldstein and Kitaibel types in the Hungarian Natural History Museum in Budapest. Annales historico-naturales Musei nationalis hungarici 84: 33-53. 
Kožuharov, S.I. \& Anchev, M.E. (eds., 2012). Florae Reipublicae Bulgaricae. Vol. 11. Editio Academica "Professor Marin Drinov", Serdicae, 523 pp.

KuPCSOK, J. (1912). Campanula macrostachya. Magyar Botanikai Lapok 11: 282.

MalatinsZKY, Á., MravCSIK, Z. \& DedÁK, D. (2014). Florisztikai adatok a Cserhát felhagyott szőlőiből. (Floristical data from abandoned vineyards of Cserhát Hills.). Kitaibelia 19(2): 260-266.

MARHOLD, K. \& HINDÁK, F. (eds., 1998). Checklist of non-vascular and vascular plants of Slovakia. VEDA, Bratislava, 688 pp.

MEUSEL, H. \& JäGER, E.J. (1992). Vergleichende Chorologie der zentraleuropäischen Flora. Text u. Karten. Bd. 3., Gustav Fischer Verlag Stuttgart New York, 688 pp.

Michalková, E. (2007). Campanula macrostachya Waldst. et Kit. ex Willd. (Campanulaceae). In: Mráz, P. (ed.): Chromosome number and ploidy level reports from Central Europe. 3. Reports (33-34), Biologia (Bratislava) 62: 507-510.

NAGY, J. (2007). A Börzsöny hegység edényes flórája. (Vascular flora of the Börzsöny Mountains). Rosalia 2. Duna-Ipoly Nemzeti Park Igazgatóság, Budapest, 378 pp.

NikLfeld, H. (1971). Bericht über die Kartierung der Flora Mitteleuropas. Taxon 20(4): 545-571.

OBRadović, M. (1974). Campanulaceae A. L. Juss. In: Josifović, M. (ed.): Flora SR Srbije. 6. Srpska Akademija Nauka i Umetnosti. Beograd. VI/1. pp. 528-573.

OpREA, A. (2005). Lista critică a plantelor vasculare din România. Edit. Univ. „Al. I. Cuza", Iaşi: 488 pp.

PeliKán, P. (ed., 2005). Geology of the Bükk Mountains: explanatory book to the Geological map of the Bükk Mountains (1:50 000). Budapest, Magyar Állami Földtani Intézet, $284 \mathrm{pp}$.

PifKó, D. \& BARINA, Z. (2004). Adatok a Bükkalja flórájához. (Floristic data of the territory of the "Bükkalja" region (N-Hungary)). Kitaibelia 9(1): 151-164.

ProdÁn, Gy. (1909). Adatok a Bükk- és előhegyeinek flórájához. Botanikai közlemények 8(3): 103-117.

SAG, G. \& GoTTHARD, D. (1985). Plantes de Hongrie étrangères à la flore française et leur répartition, Bulletin de la Société Botanique de France. Lettres Botaniques 132(4-5): 349-358.

SCHMOTzER, A. (2015). Ceratocephala testiculata (Crantz) Roth és további adatok a Bükkalja flórájához. (Ceratocephala testiculata (Crantz) Roth and further data to the flora of the foothills of Bükk Mts. ('Bükkalja', NE Hungary)). Kitaibelia 20(1):81-142.

Shabanova, G.A., Izverskaya, T.I. \& Ghendov, V.S. (2014). Flora and Vegetation of Bujac Steppes of the Republic of Moldova. Chisinau. Eco-TIRAS, $324 \mathrm{pp}$.

Sonkoly, J. (2014). Adatok Miskolc és a Bükk hegység flórájának ismeretéhez. (Floristic data from Miskolc and the Bükk Mountains (N Hungary)). Kitaibelia 19(2): 267-274.

Soó, R. (1937). A Mátrahegység és környékének flórája. Magyar Flóraművek I. Debrecen, $89 \mathrm{pp}$.

Soó, R. (1943). Előmunkálatok a Bükkhegység és környéke flórájához. Botanikai közlemények 40: 169-221.

Soó, R. (1968). A magyar flóra és vegetáció rendszertani-növényföldrajzi kézikönyve. (Synopsis systematico-geobotanica florae vegetationisque Hungariae). Akadémiai Kiadó. Budapest, Vol. 3. pp. 449-450. 
SRAmkó, G., Magos, G., Molnár, Cs. \& Urbán, L. (2008). Adatok a Mátra és környéke edényes flórájának ismeretéhez. (Data to the knowledge of the vascular flora of the Mátra Mountains and its surroundings). Kitaibelia 13(1): 74-93.

Sütő, L., McIntosh, R.W., Hevesi, A. \& Veress, M. (2015). Bükk Plateau: A Karst Landscape. In: Lóczy, D. (ed.): Landscapes and Landforms of Hungary. Springer International Publishing, pp. 189-199.

TAKÁcs, A., NAGY, T, FeKeTe, R. Lovas-Kiss, Á., LJuBKA, T., LÖKI, V., LisZTes-Szabó, Zs. \& MolnáR, V.A. (2015a). A Debreceni Egyetem Herbáriuma (DE) I.: A „Soó Rezső Herbárium". (The herbarium of Debrecen University (DE) I. The "Rezső Soó Herbarium"). Kitaibelia 19(1): 142-155.

TAKÁCS, A., SÜVEGES, K., LJUBKA, T., LÖKI, V., LiszTes-Szabó, Zs. \& MolnÁR, V.A. (2015b). A Debreceni Egyetem Herbáriuma (DE) II.: A „Siroki Zoltán Herbárium” (The Herbarium of Debrecen University (DE) II.: The „Zoltán Siroki Herbarium”). Kitaibelia 20(1): 15-22.

TEofilovski, A. (2011). Contributions to the flora of the Republic of Macedonia. Skopje, $142 \mathrm{pp}$.

Turis, P., Kliment, J., Feráková, V., Dítě, D., Eliáš, P., Hrivnák, R. KošŤáL, J., ŠuvadA, R., MrÁz, P. \& BERnátovÁ, D. (2014a). Red List of vascular plants of the Carpathian part of Slovakia. Thaiszia - Journal of Botany 24(1): 35-87.

Turis, P., Eliáš, P., Schmotzer, A., Király, G., Schneider, E., Kuciel, H., Szewczyk, M., Kozurak, A., AntosyaK, T., VoloschchuK, M., Lazarević \& LustyK, P. (2014b). Red list of vascular plants of the Carpathians. In: KADLEČ́́K, J. (ed.): Carpathian red list of forest habitats and species (Draft). The State Nature Conservancy of the Slovak Republic, pp. 44-105.

VojTKó, A. (2001). A Bükk hegység flórája. (Flora of the Bükk Mountains). Sorbus 2001, Eger, 340 pp.

Waldstein, F. A. \& Kitaibel, P. (1811). Descriptiones et Icones Plantarum Rariorum Hungariae. Viennae, Volume 3, pp. 222-310.

Willdenow, D. C. L. (1809). Enumeratio Plantarum Horti Regii Botanici Berolinensis. Libraria Scholae realis, Berolini, $1099 \mathrm{pp}$.

WINTERL, J.J. (1788). (facsimile: 1972). Index Horti Botanici Universitatis Hungaricae, quac Pestini est. Pest, 161 pp.

Witkowski, Z.J., KRóL, W. \& Solarz, W. (eds., 2003). Carpathian list of endangered species. WWF and Institute of Nature Conservation, Polish Academy of Sciences, Vienna-Krakow.

(submitted: 17.11.2016, accepted: 14.12.2016) 